\title{
Improvement of MSME Sales and Capital Management through a Website-Based Marketplace System
}

\author{
I Putu Sura Sanjaya ${ }^{\mathrm{a} 1}$, Oka Sudana ${ }^{\mathrm{a} 2}$, I Putu Arya Dharmaadi ${ }^{\mathrm{a} 3}$ \\ anformation Technology Study Program, Faculty of Engineering, Udayana University \\ Bukit Jimbaran, Bali, Indonesia, phone. (0361) 701806 \\ e-mail: ${ }^{1}$ surasanjaya@gmail.com, ${ }^{2}$ agungokas@unud.ac.id, ${ }^{3}$ aryadharmaadi@gmail.com
}

\begin{abstract}
Abstrak
Usaha Mikro Kecil dan Menengah (UMKM) memiliki potensi yang cukup baik untuk mengatasi kemiskanan, karena memiliki kontribusi penyerapan sebesar 99,45 persen. UMKM dapat dikembangkan dengan pemanfaatan marketplace, namun marketplace yang ada saat ini belum mampu mengatasi permasalah yang dihadapi oleh UMKM. Salah satu masalah yang dihadapi oleh pelaku UMKM adalah kesulitan dalam akses permodalan. Permodalan UMKM pada umumnya diperoleh dari pihak bank, namun pelaku UMKM dibebani oleh diperlukannya agunan untuk mengajukan pinjaman. Berdasarkan permasalahan tersebut maka dibangun sebuah sistem informasi marketplace produk UMKM dengan fitur peer-to-peer lending yang dapat membantu pelaku UMKM melakukan pemasaran produk sekaligus pengajuan pinjaman dengan syarat yang mudah serta tanpa adanya agunan. Pengujian sistem dengan metode black box menunjukan bahwa seluruh fitur berfungsi dengan baik dan sesuai dengan fungsionalitas yang diharapkan. Pengujian dengan metode acceptance testing pada pelaku UMKM memperoleh rata-rata skor sebesar $89,25 \%$, sehingga dapat disimpulkan bahwa sistem dapat diterima dan sesuai dengan kebutuhan pelaku UMKM di Kabupaten Gianyar.
\end{abstract}

Kata kunci: Sistem Informasi, Marketplace, Website, UMKM, Peer-to-Peer Lending

\section{Abstract}

Micro, Small and Medium Enterprises (MSMEs) have a good enough potential to overcome poverty, because they have an absorption contribution of 99.45 percent. MSMEs can be developed by utilizing e-marketplaces, but the existing marketplaces have not been able to solve the problems faced by MSMEs. One of the problems faced by MSME actors is difficulty in accessing capital. In general, MSME capital is obtained from the bank, but MSME actors are burdened by the need for collateral to apply for loans. Based on these problems, a marketplace information system for MSME products was built with peer-to-peer lending features that can help MSMEs do product marketing as well as apply for loans on easy terms and without any collateral. Testing the system with the black box method shows that all features are functioning properly and in accordance with the expected functionality. Testing with the acceptance testing method for MSME actors obtained an average score of $89.25 \%$, so it can be concluded that the system is acceptable and in accordance with the needs of MSME players in Gianyar Regency.

Keywords : Information Systems, Marketplace, Website, UMKM, Peer-to-Peer Lending

\section{Introduction}

Micro, Small and Medium Enterprises (MSMEs) are productive community businesses with individual ownership status or business entities that have been regulated in accordance with Law no. 20 of 2008. The large potential of MSMEs can be seen from the contribution of employment of 99.45 percent [1]. Improving the quality and development of MSMEs will be able to absorb labor, so as to reduce the unemployment rate. Reduced unemployment indicates an increase in the welfare of a country, so it can be concluded that it reduces the poverty level of that country [2]. One of the regions in Indonesia that has a fairly large number of MSMEs is Bali Province, this can be seen from the growth in Gross Regional Domestic Income (PDRB). According to data from the Bali Provincial Office of Cooperatives and SMEs, the contribution of MSMEs in the formation of PDRB and employment is 54.22\% [3]. MSMEs in Indonesia can be divided into two sectors, namely the formal and informal UMKM sectors. The difference between the two sectors lies in the completeness of administration and the formal requirements that apply in the Republic of Indonesia [4]. 
Gianyar Regency is a district that has the largest number of informal MSMEs in Bali Province. The large potential of MSMEs encourages the government to empower the management and marketing of MSMEs with various internet-based business programs, one of which is the use of e-marketplaces. Using the e-marketplace will make it easier for MSME players to market their products and make it easier for consumers to purchase products [5]. Currently, there are many e-marketplaces that can be used by MSME players to do online marketing, however The e-marketplace has not been able to solve the problems faced by MSME players. One of the problems faced by MSME actors is lack of access to capital [6]. Emarketplaces generally only provide credit services to customers who want to buy products from a

store. Banks generally provide access to capital, however, banks tend to be careful. Banks tend to be cautious due to several factors such as administrative completeness, marketing and production capabilities, and collateral is required to apply for a loan [7].

Problems faced by MSME players can be overcome by implementing an e-marketplace information system with a peer-to-peer lending feature. Peer-to-peer lending is a service that can bring together creditors and debtors, in which in this study, MSME entities can become debtors and customer entities can become creditors [8]. E-marketplaces with peer-to-peer lending features can help MSME players apply for loans because MSMEs can apply for loans only by verifying the applicant's NPWP, SIUP, KTP files, and without collateral. The emarketplace information system with the peer-to-peer lending feature can make it easier for MSME players, because online product marketing and access to capital can be accessed in one information system [9]-[11].

\section{Research Method}

The marketplace for MSME products with the peer-to-peer lending feature is the application of a marketplace information system consisting of many MSME actors and many customer entities. The peer-to-peer lending feature is a service that can bring together creditors and debtors [8]. The research flow of the design and development of the MSME product marketplace system with peer-to-peer lending features includes needs analysis, system workflow design, database and interface design, and system implementation and testing.

\subsection{Overview of Peer-to-Peer Lending Features}

The marketplace information system for MSME products with peer-to-peer lending features is a marketplace information system that consists of many MSME actors and many customers. In addition to providing buying and selling services for MSME products, the marketplace information system for MSME products also provides peer-to-peer lending services. Peer-to-peer lending service is a service that can bring together creditors and debtors. MSME actors can act as debtors and customer entities can act as creditors. MSME players can apply for loans with easy terms and without collateral.

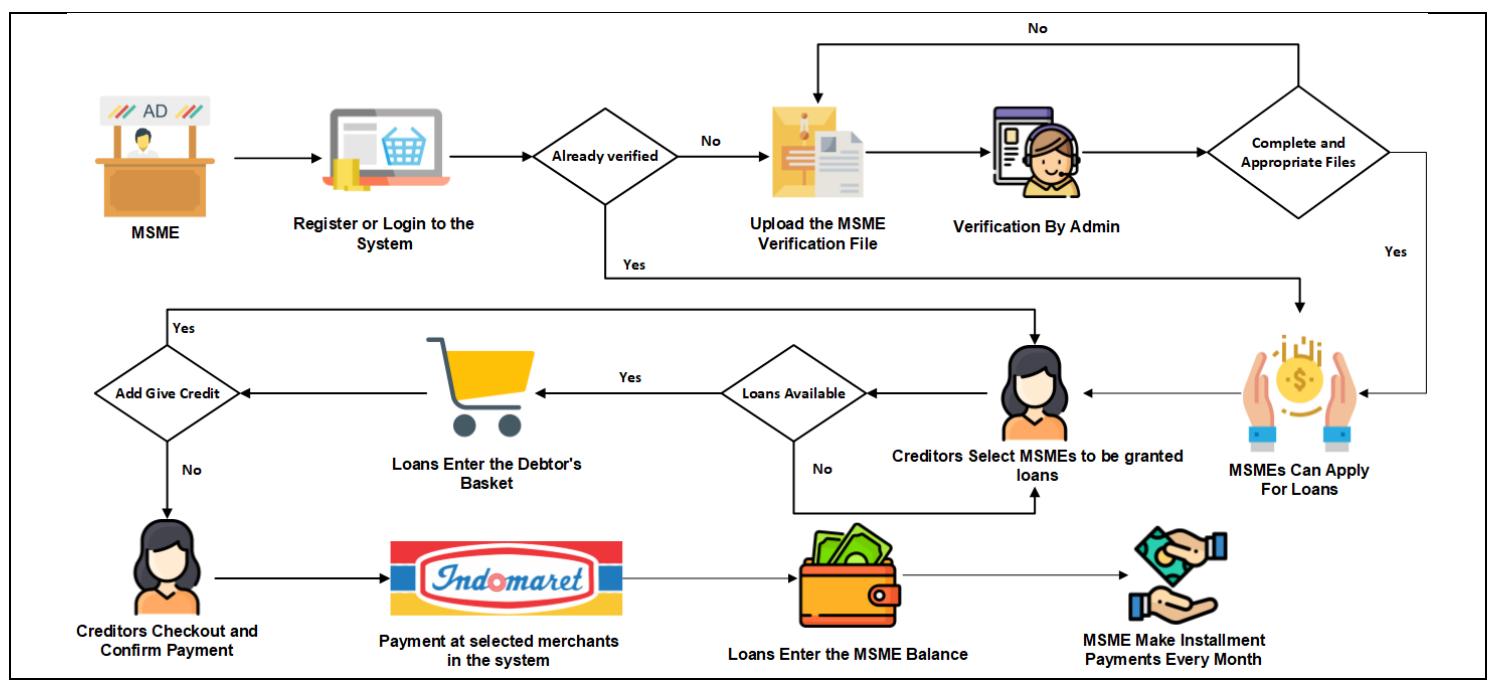

Figure 1. Peer-to-Peer Lending Features Overview 
Figure 1 shows an overview of the peer-to-peer lending features that exist in the MSME product marketplace information system. The peer-to-peer lending feature on the e-marketplace of MSME products can make it easier for MSME players to apply for loans on easy terms and without any collateral. Lending and installment payments have been integrated with epayments, so that they can cover one of the user's needs, namely the security aspect [12]. The e-marketplace of MSME products with peer-to-peer lending features can help MSME players carry out company development, because product marketing and access to capital can be accessed through one information system.

\section{$2.2 \quad$ Use Case Customer Actor}

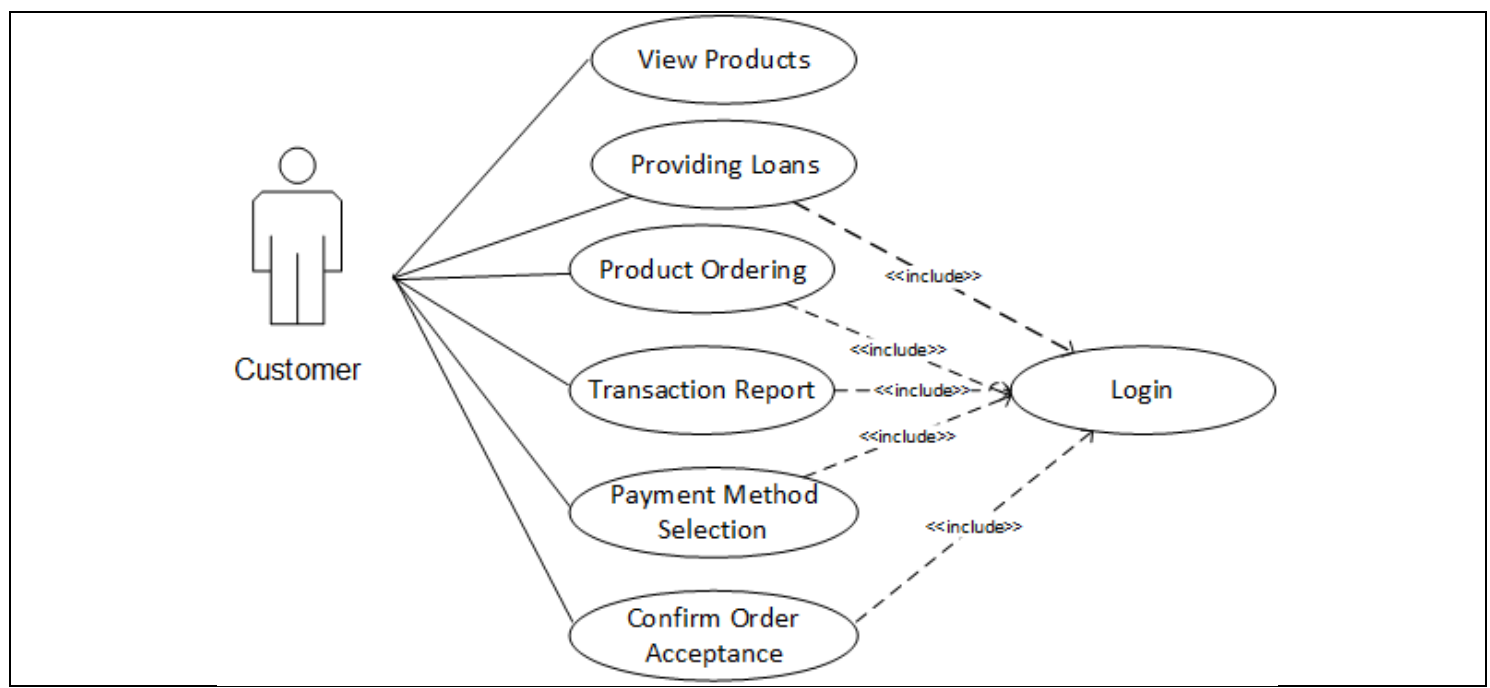

Figure 2. Use Case Customer Actor

Figure 2 shows the use case of customer actors in information systems e-marketplace for UMKM products. Features that can be accessed by customer actors are product data, providing loans for MSME actor, ordering products, transaction reports, selecting payment methods, and confirming order acceptance. Customer actors can access features to view product data without having to log in first.

\subsection{Use Case MSME Actor}

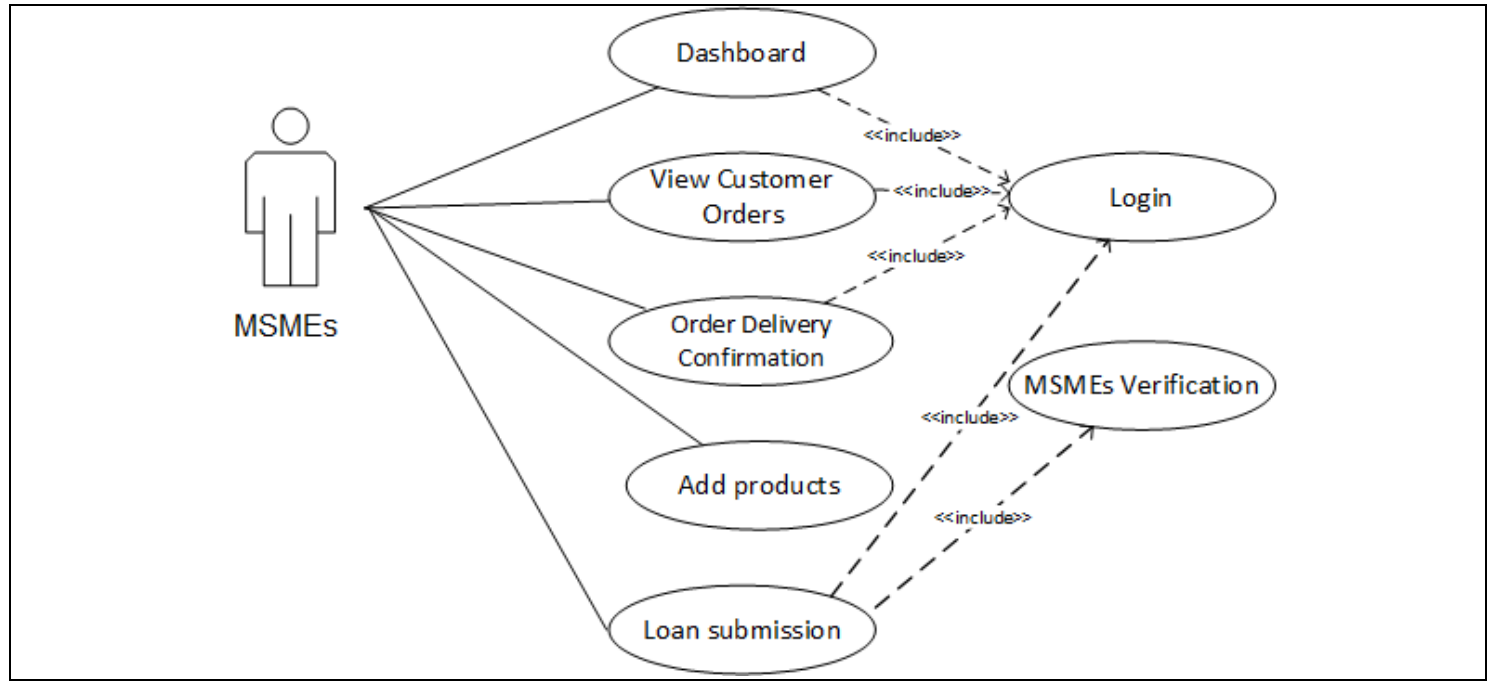

Figure 3. Use Case MSME Actor 
Figure 3 shows the use case of MSME actors from the e-marketplace information system for UMKM products.MSME actors can access dashboard features, customer order management, order delivery confirmation, product management, and loan applications. All features can only be accessed if the MSME player has previously performed the login process. The loan management feature can only be accessed by MSME players who have verified the UMKM file.

\section{Literature Review}

\subsection{Information Systems}

The information system is an activity of organized procedures, and when executed it will provide relevant information to information system users at various levels of the organization [13]. Information systems have benefits at various levels of the organization, one of which is to manage data so that it remains available and data management can be done more easily, quickly, and transparently [14].

\subsection{E-marketplace}

The development of information technology indirectly forms a market called an emarketplace. It is felt that the e-marketplace commerce system can be used as a medium for promotion, communication, and can cut the distribution chain because products can be marketed directly to the final consumer without intermediaries [15]. E-marketplaces can be divided into three stages, namely commodity exchanges, value added services, and knowledge networks [16]. There is a fundamental difference between e-marketplace and e-commerce, namely e-commerce has only one vendor, whereas e-marketplace consists of many vendors [17].

\subsection{Website}

A website is a collection of web pages published to the internet, and has a domain address or URL that can be accessed by internet users [18]. The advantage of a website compared to other platforms is that website-based applications can be accessed without installing [19]. Website services are facilities provided by website websites to provide services in the form of information to other systems, so that the system communicates with services [20].

\subsection{Peer-to-Peer Lending}

Peer-to-peer lending is a platform that can bring together creditors and debtors directly, and to make loans without the debtor's assets being held. Peer-to-peer lending consists of three stakeholders who have their respective processes, namely the debtor, creditor, and operator. Debtors can register in the peer-to-peer lending system then debtors can apply for loans. The peer-to-peer lending operator will conduct a creditworthiness analysis of the loan submitted by the debtor before being displayed to the creditor. The lending process can be carried out by the creditor after carrying out the registration process, after registering, the creditor can see the debtor's profile and decide who to give a loan to [8], [21]. 


\subsection{Standart Operation Procedure (SOP)}

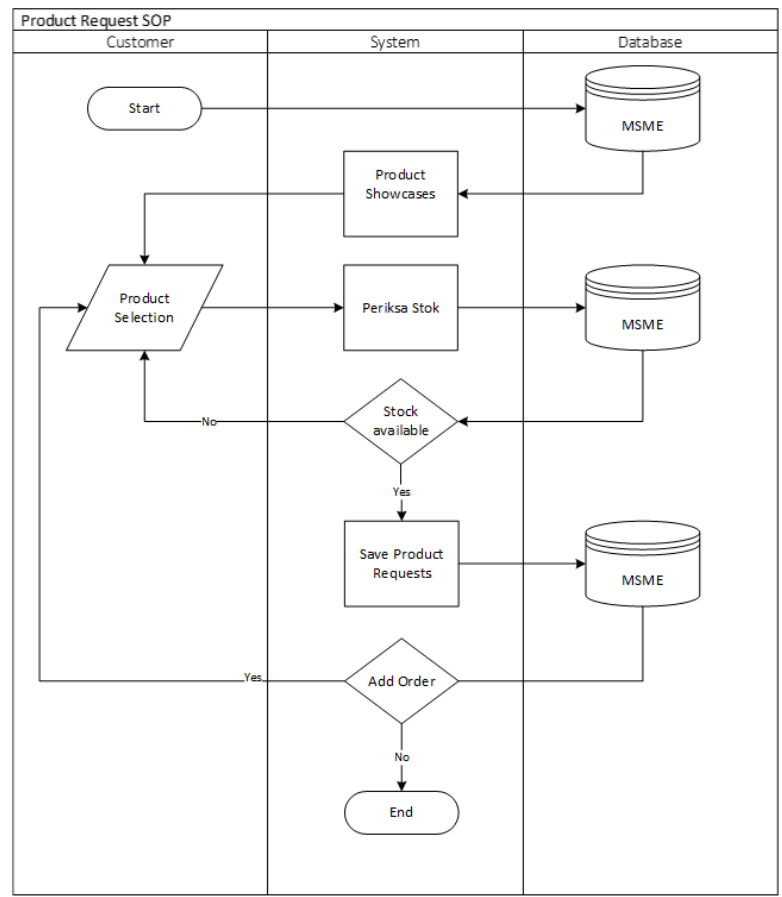

Figure 4. Product Request SOP

Figure 4 is a product demand SOP that shows the flow of product demand from customers to MSME players. Customers can choose a product then the customer order will be displayed to the MSME actors

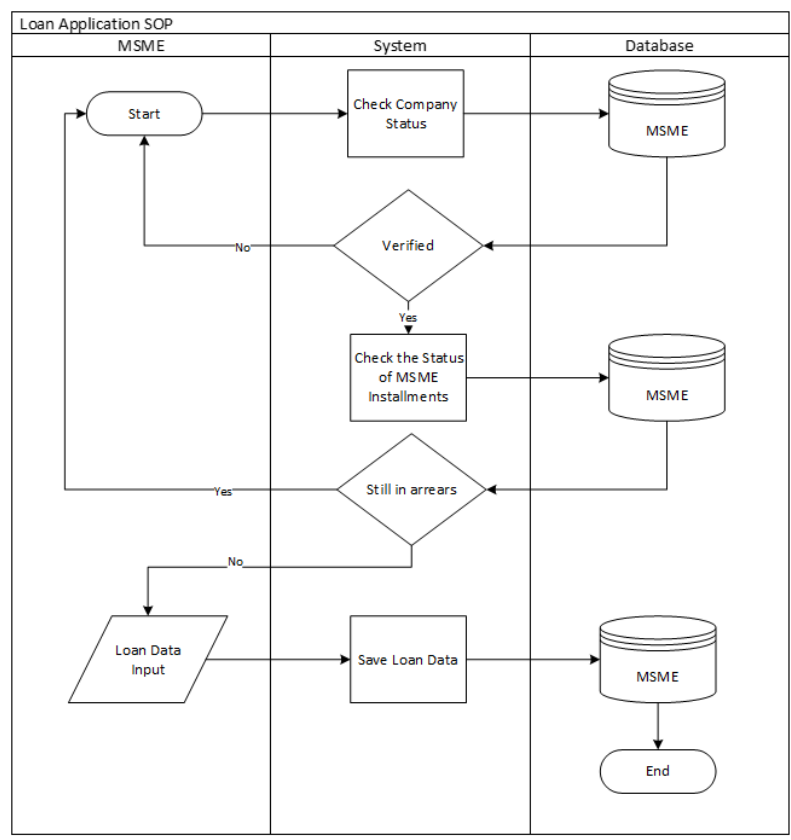

Figure 5. Loan Application SOP

Figure 5 is an SOP for loan applications that shows the flow of loan applications made by MSME actors. Applications for loans are made by MSME actors using peer-to-peer lending 
services in the system. UMKM players can only apply for loans if the status of the UMKM has been verified and do not have arrears in installments

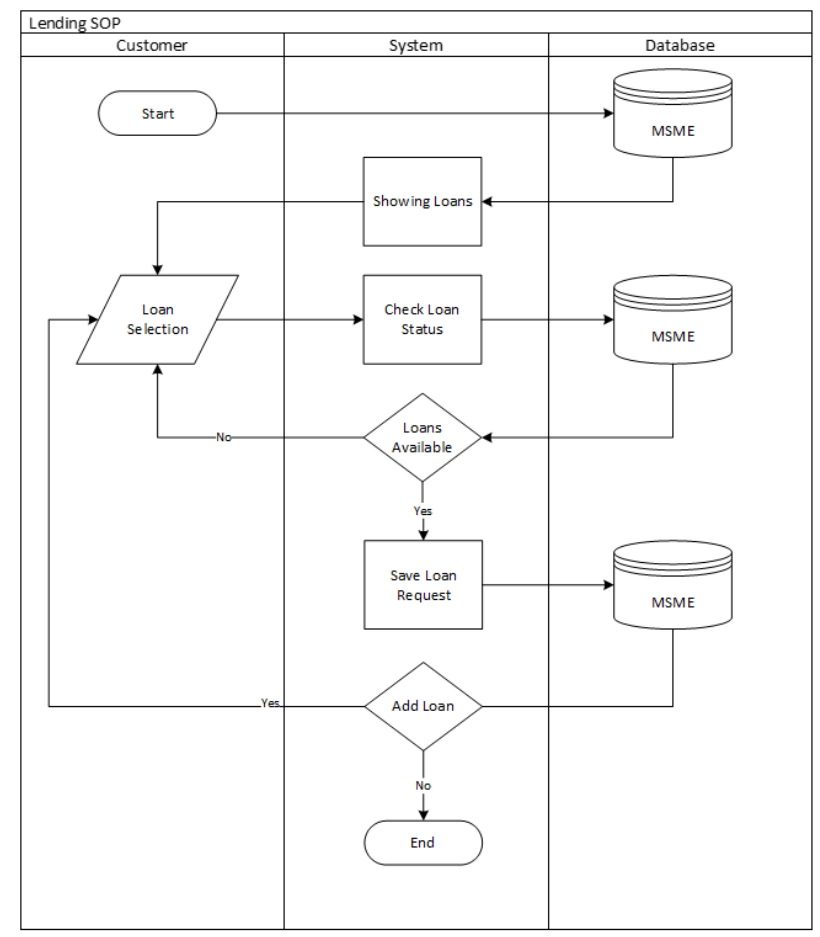

Figure 6. Lending SOP

Figure 6 is a loan application SOP that shows the flow of the loan process carried out by customer entities to MSME players. Customers can provide loans to several MSME players then get monthly installment payments from MSME players.

\section{Result and Discussion}

Results and discussion present the results of designing an information system for emarketplace for MSME products with peer-to-peer lending features. The results and discussion of this study are as follows.

\subsection{Context Diagram and Level 0 DFD}

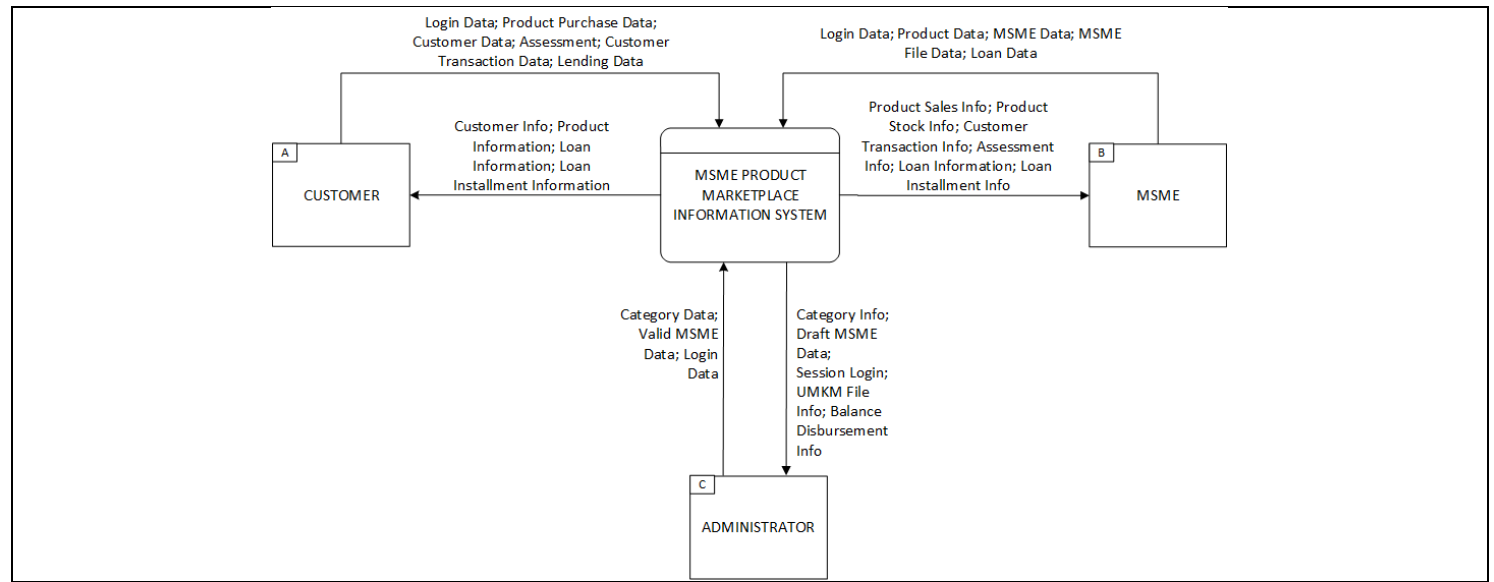

Figure 7. Context Diagram Design

Figure 7 is a context diagram of the e-marketplace information system for MSME products, which consists of three entities, namely admin entities, MSME players, and 
customers. The three entities have a relationship with each other and boil down to the system. Context diagram shows the relationship between the entities involved in the system where the system is described in general terms [22].

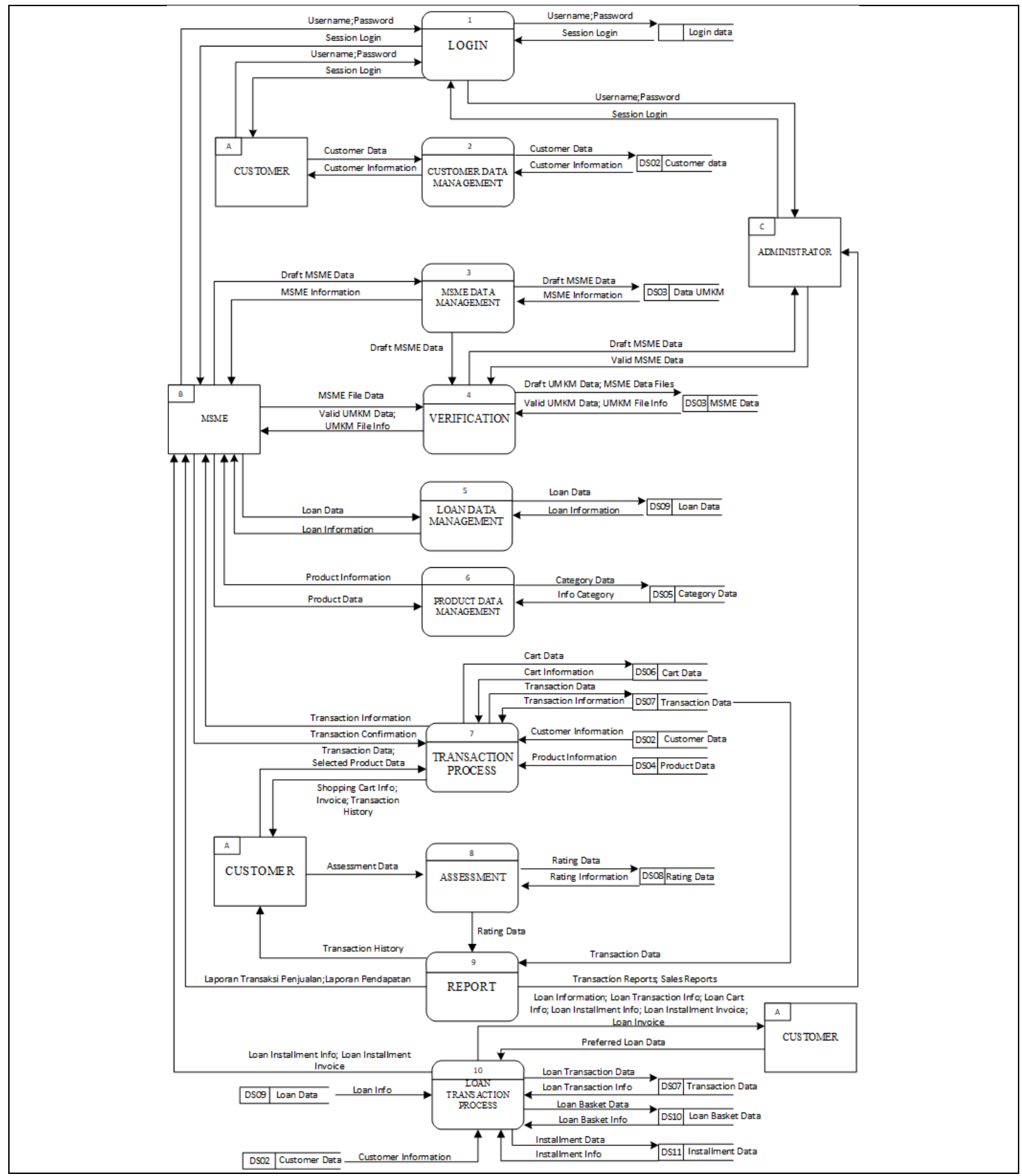

Figure 8. DFD Level 0

Figure 8 is DFD Level 0 of the MSME product e-marketplace information system which describes the overall system. DFD can be explained as a data logic model that describes the origin of the data and the purpose of the data released by the system [23]. There are ten processes in the information system, namely registration, verification, loan data management, product data management, transaction processing, assessment, reports, and loan transaction processes. 


\subsection{Implementation}

The e-marketplace information system for MSME products with peer-to-peer lending features consists of three entities, namely customer entities, MSME players, and administrator entities. The results of the implementation of the e-marketplace information system for MSME products with peer-to-peer lending features are as follows.

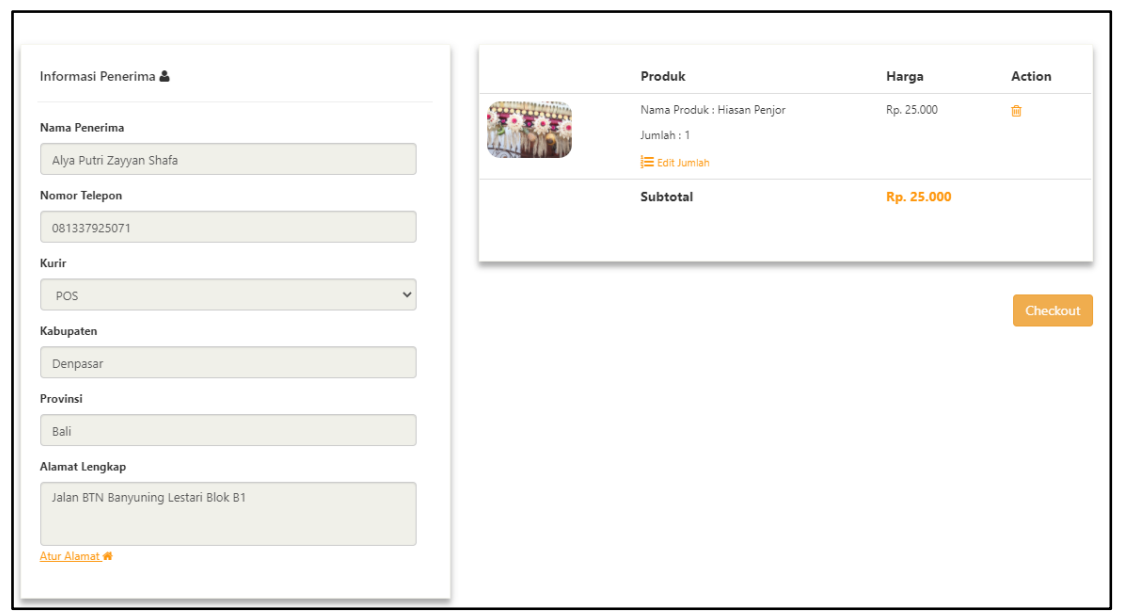

Figure 9. Shopping Cart Page

Figure 9 is a shopping cart page that is used to display products that have been selected by Shopping customers. Customers are required to fill in the form provided such as the courier chosen for order delivery, besides that the customer's personal data has been filled automatically according to the customer's profile.

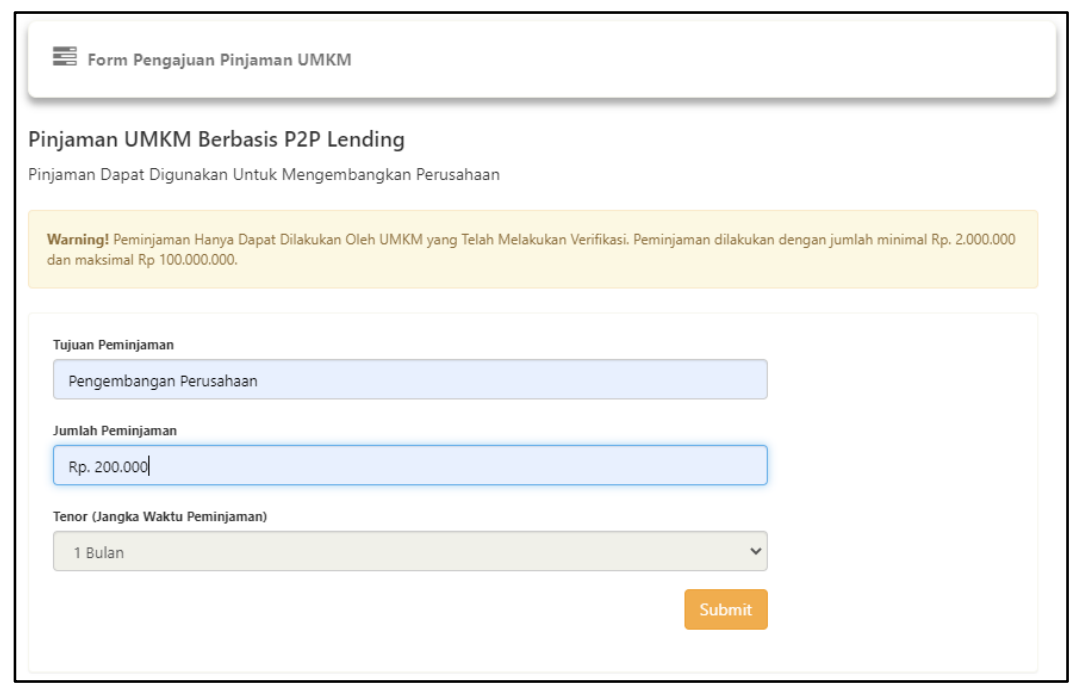

Figure 10. Loan Application Page

Figure 10 is a loan application page for MSME players registered in the system. Submitting for loans is part of the peer-to-peer lending feature, so that MSME actors can apply for loans without collateral and can be met with creditors. 


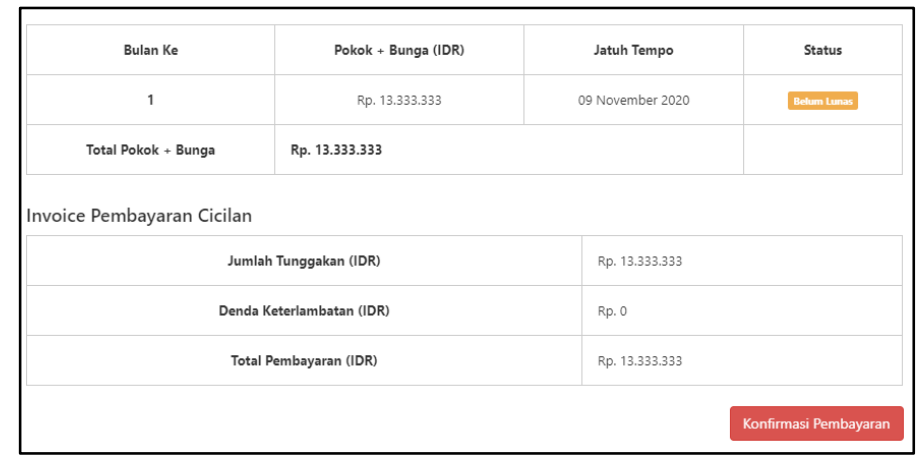

Figure 11. Installment Invoice Page

Figure 11 is an invoice page for installment payments made by MSMEs every month. The installment payment invoice displays the installment details and the amount to be paid. The amount paid includes the amount of installment payments and late payment penalties if the payment is made past the predetermined due date.

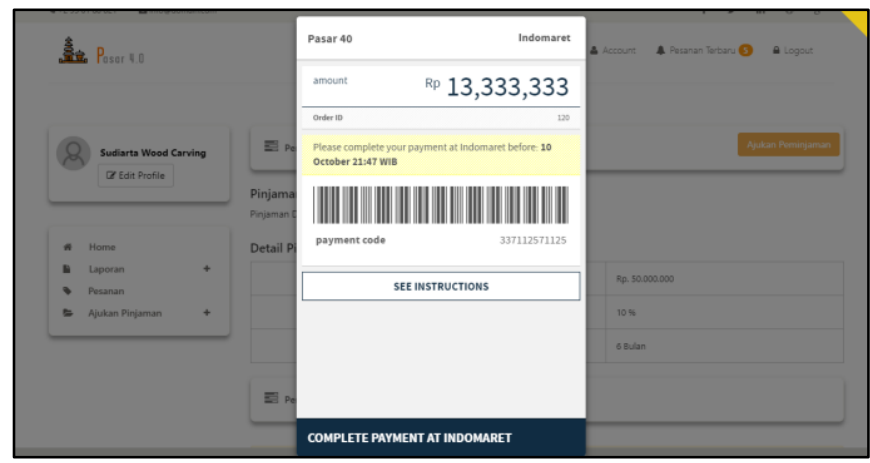

Figure 12. Installment Payment Confirmation Page

Figure 12 is a confirmation page for installment payments for MSME players. Confirmation is made if the UMKM players will make monthly installment payments. Payment confirmation is made by selecting the payment method to be used, such as bank transfers, electronic wallets, and minimarket outlets.

\subsection{Black Box Testing}

Black box testing is a method used to test a system with the aim of checking the suitability of system functions with the expected functions. This test focuses on incorrect functionality, erroneous data structures, and interface errors [25]. Black box testing is carried out on each entity in the system. The results of black box testing on the system are as in Table 1 and Table 2.

Table 1. Customer Entity Black Box Testing

\begin{tabular}{llll}
\hline No. & Functionality Testing & Expected Results & Conclusion \\
\hline 1 & $\begin{array}{l}\text { The UMKM entity logs in } \\
\text { correctly (no field is empty } \\
\text { and fills in the appropriate } \\
\text { email and password) }\end{array}$ & $\begin{array}{l}\text { Customers will be given login access } \\
\text { and will be redirected to the main } \\
\text { page of the customer entity }\end{array}$ & Success \\
\hline 2 & $\begin{array}{l}\text { Incorrectly added product } \\
\text { (the number of product } \\
\text { requests does not exceed the } \\
\text { stock held) }\end{array}$ & $\begin{array}{l}\text { The system will refuse to add a } \\
\text { shopping cart and will display an alert } \\
\text { that the number of product requests }\end{array}$ & \\
\hline 3 & $\begin{array}{l}\text { Add products correctly } \\
\text { (customer has logged in and } \\
\text { the number of product } \\
\text { requests does not exceed }\end{array}$ & The system will store product request & Success \\
shopping cart page & & \\
\hline
\end{tabular}




\begin{tabular}{llll}
\hline & stock) & & \\
\hline 4 & $\begin{array}{l}\text { Incorrectly adding MSME } \\
\text { loan data to the loan basket } \\
\text { (loan data that has been } \\
\text { entered into the active basket } \\
\text { and will display an alert that the }\end{array}$ & \\
is added back) & & & \\
\hline 5 & $\begin{array}{l}\text { Adding loan data to the } \\
\text { basket correctly (loan data } \\
\text { has not been entered into an active loan basket and will display an } \\
\text { active basket and active loan the basket } \\
\text { status) }\end{array}$
\end{tabular}

Tabel 2. MSMEs Entity Black Box Testing

\begin{tabular}{|c|c|c|c|}
\hline No. & Functionality Testing & Expected Results & Conclusion \\
\hline 1 & $\begin{array}{l}\text { The UMKM entity logs in } \\
\text { correctly (no field is empty } \\
\text { and fills in the email and } \\
\text { password correctly) }\end{array}$ & $\begin{array}{l}\text { The system receives login access and } \\
\text { the UMKM will be redirected to the } \\
\text { UMKM dashboard page }\end{array}$ & Success \\
\hline 2 & $\begin{array}{l}\text { Adding product data correctly } \\
\text { (product data is filled in } \\
\text { correctly and there are no } \\
\text { empty fields) }\end{array}$ & $\begin{array}{l}\text { The system will store product data } \\
\text { and will be displayed on the MSME } \\
\text { dashboard }\end{array}$ & Success \\
\hline 3 & $\begin{array}{l}\text { Add loan data correctly } \\
\text { (fields are filled in } \\
\text { completely) then click the } \\
\text { "Submit" button }\end{array}$ & $\begin{array}{l}\text { The system will store new loan data, } \\
\text { then new loan data will be displayed } \\
\text { on the MSME dashboard }\end{array}$ & Success \\
\hline 4 & $\begin{array}{l}\text { Access the added loan } \\
\text { feature but have not verified } \\
\text { the UMKM }\end{array}$ & $\begin{array}{l}\text { The system will reject UMKM and will } \\
\text { display an alert that UMKM has not } \\
\text { verified and will be redirected to the } \\
\text { verification file upload page }\end{array}$ & Success \\
\hline 5 & $\begin{array}{l}\text { Confirming delivery of } \\
\text { customer orders by inputting } \\
\text { the receipt number then } \\
\text { clicking the "Submit" button }\end{array}$ & $\begin{array}{l}\text { The system will confirm the delivery of } \\
\text { the order to the customer, the order } \\
\text { status will be changed to "Already } \\
\text { Sent" }\end{array}$ & Success \\
\hline
\end{tabular}

\subsection{Quistionnare Analysis}

The questionnaire is a data collection technique by submitting statements to be answered by respondents [26]. Testing was carried out on 10 MSME owners in the area around Gianyar Regency. The Likert scale is a scale used to calculate the results of the questionnaire from this study.

Table 3. Questionnaire Calculation Results

\begin{tabular}{clccc}
\hline Variable & Testing Scenarios & Total Score & Percentage & Category \\
\hline P1 & $\begin{array}{l}\text { The system works well and is easy to } \\
\text { use }\end{array}$ & 47 & $94 \%$ & SS \\
P2 & $\begin{array}{l}\text { Feel comfortable with the display system } \\
\text { used }\end{array}$ & 41 & $82 \%$ & S \\
P3 & $\begin{array}{l}\text { All features are complete and functioning } \\
\text { properly } \\
\text { The system responds according to the }\end{array}$ & 41 & $82 \%$ & S \\
data required \\
P5 & $\begin{array}{l}\text { The system helps MSMEs in product } \\
\text { management }\end{array}$ & 43 & $96 \%$ & SS \\
P6 & $\begin{array}{l}\text { The system helps MSMEs in online } \\
\text { marketing }\end{array}$ & 47 & $86 \%$ & SS \\
P7 & $\begin{array}{l}\text { The system helps MSMEs to apply for } \\
\text { loans online }\end{array}$ & 49 & $94 \%$ & SS \\
P8 & $\begin{array}{l}\text { The system makes it easy for MSMEs to } \\
\text { make loan installment payments online } \\
\text { The system makes it easier for MSME }\end{array}$ & 48 & $96 \%$ & SS \\
P9 & $\begin{array}{l}\text { Them } \\
\text { PS }\end{array}$ & $92 \%$ & SS
\end{tabular}


players to manage orders

The system works well and is easy to

$90 \%$

SS use

Based on the results of the calculations in Table 3, where the test has an average value of $90 \%$ with the SS category or "Strongly Agree", so it can be said that the marketplace information system for MSME products is very acceptable and in accordance with the needs of MSME players. The system is highly accepted by MSME players, especially the peer-to-peer (P2P) lending feature, because the marketplace information system with the peer-to-peer lending feature can help MSME players market products online and help MSME players apply for loans online. MSME players can apply for loans online with easy conditions such as verifying the NPWP, SIUP, and KTP of the UMKM owner. The requirements are categorized as easy because most of the MSME actors in Gianyar Regency already have NPWP, SIUP, and KTP files. In addition, applying for loans is considered easier than banks because loan applications can be made without collateral or retained MSME assets.

\section{Conclusion}

This research succeeded in developing a marketplace information system for MSME products with peer-to-peer (P2P) lending features. There are several features that can be accessed by each entity. The entities associated with this system are customer entities, MSME actors, and administrators. The first system testing was carried out using the Black Box method, showing that all system functionality was functioning as expected. Testing with the questionnaire method involved 10 MSME actors and with 9 variables. Based on the 9 variables tested, the average result is $90 \%$ with the category "Strongly Agree". So it can be concluded that the designed system can be implemented well, especially for MSME players who want to do product marketing online and MSME players who want to apply for loans online without any conditions that burden MSME players.

\section{References}

[1] Y. R. Suci, S. Tinggi, and I. Ekonomi, "Perkembangan UMKM (Usaha Mikro Kecil Menengah) di Indonesia," vol. 6, no. 1, Jurnal Ilmiah fakultasi Ekonomi, pp. 51-58.

[2] F. D. Kurniawan and L. Fauziah, "Pemberdayaan Usaha Mikro Kecil Dan Menengah (Umkm) Dalam Penanggulangan Kemiskinan," vol. 2, no. 2, JKMP (Jurnal Kebijakan dan Manajemen Publik), p. 165.

[3] A. A. N. G. Maheswara, N. D. Setiawina, and I. A. N. Saskara, "Analisis Faktor-Faktor Yang Mempengaruhi Pendapatan Ukm Sektor Perdagangan Di Kota Denpasar," vol. 5, no. 12, E-Jurnal Ekonomi dan Bisnis Universitas Udayana, pp. 4271-4298.

[4] H. H. Sawitri, "Potret Usaha Kecil Mikro (UKM) di Bali Implementasi Bantuan Modal dari Kemenkop tahun 2015-2016," vol. 147, Semnas Fekon, pp. 11-40.

[5] I. Gusti Ngurah Wira Dharma, I. Made Sukarsa, and N. Putu Sutramiani, "Rancang Bangun Sistem E-Commerce Marketplace Gypsum Berbasis Cloud Computing," vol. 7, no. 1, Jurnal Ilmiah Merpati (Menara Penelitian Akademika Teknologi Informasi), p. 37.

[6] M. A. Fauza, M. Saifi, and Dwiatmanto, "Analisis Sistem dan Prosedur Pemberian Kredit Modal Kerja guna Mendukung Pengendalian Kredit (Studi Kasus pada PT Bank Rakyat Indonesia (Persero) Tbk Cabang Kawi Malang) Maela," vol. 39, no. 1, Jurnal Administrasi Bisnis, pp. 24-33, [Online]. Available: http://administrasibisnis.studentjournal.ub.ac.id/index.php/jab/article/view/1530.

[7] H. Suprapto, "Analisis Keputusan Investasi Bagi Usaha Mikro, Kecil Dan Menengah (UMKM)," vol. 7, no. 1, Jurnal Ekonomi \& Manajemen Indonesia, pp. 22-29, [Online]. Available: http://ejurnal.unikarta.ac.id/index.php/jemi/article/view/139.

[8] A. Milne and P. Parboteeah, "The Business Models and Economics of Peer-to-Peer Lending," no. May, SSRN Electronic Journal.

[9] I. P. Sugi Almantara, A. A. K. Agung Cahyawan Wiranatha, and K. Suar Wibawa, "Sistem Informasi Penyewaan Kendaraan Bermotor Customer to Customer (C2C)," vol. 
5, no. 3, Jurnal IImiah Merpati (Menara Penelitian Akademika Teknologi Informasi), p. 9.

[10] A. Amrullah, "Perancangan Sistem Informasi Pada Smart UMKM dalam Mendukung Sleman Smart Regency," vol. 0, no. 0, Konferensi Nasional Sistem Informasi (KNSI) 2018, pp. 8-9, [Online]. Available: http://jurnal.atmaluhur.ac.id/index.php/knsi2018/article/view/341/266.

[11] M. A. Raharja, I. M. W. A. Putra, and N. P. D. Krismawintari, "IPTEKS Bagi Masyarakat Kerajinan Kayu di Desa Petulu Ubud Kabupaten Gianyar," vol. 7, no. 2.

[12] I. G. Ngurah, I. Saputra, G. Made, A. Sasmita, and A. A. K. A. C. W, "Pengembangan Sistem Keamanan untuk E-Commerce," vol. 5, no. 1, Jurnal IImiah Merpati (Menara Penelitian Akademika Teknologi Informasi), pp. 17-28.

[13] A. A. . Oka Sudana, I. M. Sukarsa, and I. M. Wahyu Saputra, "Information System of Yadnya Ceremony on Android-Based," vol. 7, no. 6, International Journal of Hybrid Information Technology, pp. 155-164.

[14] A. P. Hanifah, Y. Fitrisia, and D. Hajar, "Sistem Informasi Pelayanan Klinik Berbasis Web (Studi Kasus: Klinik Annisa Medika 2)," vol. 2, no. 3, Jurnal RESTI (Rekayasa Sistem dan Teknologi Informasi), pp. 668-673.

[15] J. Zhang, M. X. Cai, T. Lu, X. H. Sun, and J. L. Jia, "Lumbar spinal stenosis treated with polyetheretherketone pedicle screw fixation combined with interbody fusion: A follow-up assessment focusing on bone fusion rate," vol. 20, no. 12, Chinese Journal of Tissue Engineering Research, pp. 1684-1689.

[16] R. E. Indrajit, "Evolusi E-Marketplace," vol. 4, no. C, pp. 1-4.

[17] R. Yustiani and R. Yunanto, "Peran Marketplace Sebagai Alternatif Bisnis Di Era Teknologi Informasi," vol. 6, no. 2, Komputa: Jurnal IImiah Komputer dan Informatika, pp. 43-48.

[18] M. Abdurahman, "Sistem Informasi Pengaduan Pelanggan Air Berbasis Website pada PDAM KotaTernate," vol. 2, no. 1, IJIS-Indonesia Journal on Information System, pp. 18-26.

[19] I. Solikin, "Implementasi E-Modul pada Program Studi Manajemen Informatika Universitas Bina Darma Berbasis Web Mobile," vol. 2, no. 2, Jurnal RESTI (Rekayasa Sistem dan Teknologi Informasi), pp. 492-497.

[20] R. C. Dinatha, I. M. Sukarsa, and A. A. K. A. Cahyawan, "Data Exchange Service using Google Drive API," vol. 154, no. 7, International Journal of Computer Applications, pp. 12-16.

[21] A. Setiadi Saputra, "Peer To Peer Lending Di Indonesia Dan Beberapa Permasalahannya," vol. 5, no. 1, Veritas et Justitia, pp. 238-261.

[22] N. P. R. G. Dewi, O. Sudana, and M. Sukarsa, "Implementasi Diagram Tree pada Rancang Bangun Sistem Informasi Bebayuhan Oton Berbasis Web," vol. 8, no. 3, Lontar Komputer : Jurnal Ilmiah Teknologi Informasi, p. 178.

[23] T. Hardiwinata, P. W. Buana, and N. K. A. Wirdiani, "Perancangan Sistem Informasi Manajemen Rumah Sakit Modul Akuntansi Dan Keuangan," vol. 6, no. 2, Lontar Komputer: Jurnal Ilmiah Teknologi Informasi, p. 138.

[24] R. S. Tombe, R. K. Ekawati, N. F. A. Budi, A. N. Hidayanto, and P. Anussornnitisarn, "Why does people use e-payment systems in $\mathrm{C} 2 \mathrm{C}$ e-marketplace? a trust transfer perspective," vol. 2018-Janua, Proceedings of the 2nd International Conference on Informatics and Computing, ICIC 2017, pp. 1-6.

[25] R. Wahyudi et al., "Pengembangan dan Pengujian Aplikasi 'SIATAP' Sistem Informasi Tanya Apoteker Berbasis Android dan Website," vol. 1, no. 10, Jurnal RESTI, pp. 210218.

[26] A. K. Putra, R. D. Nyoto, and P. H. Sasty, "Rancang Bangun Aplikasi Marketplace Penyedia Jasa Les Private Di Kota Pontianak Berbasis Web," vol. 5, no. 1, Jurnal Sistem dan Teknologi Informasi, pp. 22-25. 